\title{
Çocukların Bilişsel Stilleri ile Duygu Düzenleme Becerileri Arasındaki İlişkinin İncelenmesi ${ }^{*}$
}

Hatice Büşra Yılmaz ${ }^{1}$

Type/Tür:

Research/Araştırma

Received/Geliş Tarihi: May 4/ 4

May1s 2020

Accepted/Kabul Tarihi:

December 9/ 9 Aralik 2020

Page numbers/Sayfa No: $417-433$

Corresponding

Author/İletişimden Sorumlu

Yazar: atufekci@gazi.edu.tr

\section{$\checkmark$ iThenticate}

This paper was checked for plagiarism using iThenticate during the preview process and before publication. / Bu çalışma ön inceleme sürecinde ve yayımlanmadan önce iThenticate yazılımı ile taranmıştır.

\section{Copyright $@ 2017$ by}

Cumhuriyet University, Faculty of Education. All rights reserved.
Aysel Tüfekci²

\section{Öz}

Çocukların gelişimsel özellikleri birbirine benzemekte ancak her birinin problem çözme sürecinde bilgiyi alma, kullanma ve hatırlama yolları birbirinden farklılaşabilmektedir. Çocukların, bireysel olarak bir problem durumuna yaklaşım şekli bilişsel stil olarak ifade edilmektedir. Çocuklar duygularını düzenlerken, bilişsel bir süreç yaşamaktadır. Duygularını yönetmek için yaşadıkları problem çözme sürecinde duyguları tanıma, işleme ve çözüme ulaşarak duyguyu yansıtma aşamalarından geçmektedir. Bilişsel stil ve duygu düzenleme becerisi çocuğun kendini denetlemesiyle ilgilidir. Bilişsel stil ile duygu düzenleme becerileri arasında bir ilişki olabileceği düşünülerek bu araştırma 48-72 aylık çocukların bilişsel stilleri ile duygu düzenleme becerileri arasındaki ilişkinin incelenmesi amacıyla yapılmıştır. Araştırma ilişkisel tarama modelinde desenlenmiştir. Araştırmanın verileri "Kansas Okul Öncesi Dönemdeki Çocuklar İçin Düşünsellik-İ̧tepisellik Ölçeği A formu (KRISP-A)" ve "Duygu Düzenleme Ölçeği (DDÖ)" ile toplanmıştır. Araştırmanın çalışma grubunu 2018-2019 eğitim öğretim yılında Ankara ili Keçiören ilçe Milli Eğitim Müdürlüğüne bağlı anaokulları ve anasınıflarına devam eden 413 çocuk oluşturmuştur. Araştırmanın sonucunda; çocukların bilişsel stilleri ile duygu düzenleme becerileri arasındaki ilişkiye bakıldığında KRISP-A Formu hata sayısı puanı ile DDÖ olumsuzluk alt faktörü ve ölçek toplam puanı arasında pozitif yönde anlamlı ilişki olduğu görülmüştür. Çocukların hızlı doğrucu, düşünsel, içtepisel veya yavaş yanlışçı olmaları ile duygu düzenleme ölçeği alt faktörleri ve ölçek toplam puanı arasında ise anlamlı bir ilişki olmadığı belirlenmiştir.

Anahtar Kelimeler: Okul öncesi dönem, erken çocukluk, bilişsel stil, duygu düzenleme, bilişsel tempo.

\section{Suggested APA Citation/Önerilen APA Atıf Biçimi:}

Yılmaz, H.B., \& Tüfekci, A. (2021). Çocukların bilişsel stilleri ile duygu düzenleme becerileri arasındaki ilişkinin incelenmesi. Cumhuriyet International Journal of Education, 10(1), 417-433. http://dx.doi.org/10.30703/cije.731550

\footnotetext{
* Çalışma birinci yazarın ikinci yazar danışmanlığında yürütmüş olduğu yüksek lisans tez çalışmasından üretilmiştir. Veri toplama araçlarının kullanım izinleri ve Ankara İl Milli Eğitim Müdürlüğünden araştırma verilerinin toplanması için gerekli izinler alınmıştır.
}

${ }^{1}$ Araştırma Görevlisi, Gazi Üniversitesi, Eğitim Bilimleri Enstitüsü, Ankara/Türkiye Research Asistant, Gazi University, Intitute of Education, Ankara/Türkiye e-mail: $\underline{\text { hbyilmaz@gazi.edu.tr }}$ ORCID ID: orcid.org/0000-0003-2563-8353

2 Dr. Öğretim Üyesi, Gazi Üniversitesi, Temel Eğitim Bölümü, Ankara/Türkiye Assist. Prof. Dr., Gazi University, Department of Primary Education, Ankara/Türkiye e-mail: atufekci@gazi.edu.tr ORCID ID: orcid.org/0000-0001-7792-5624 


\title{
An Investigation of the Relationship between Children's Cognitive Styles and Emotion Regulation Skills
}

\begin{abstract}
The developmental characteristics of children are similar, but the ways each get information, use and remember it in the problem solving process may differ from each other. The way children approach to a problem situation as an individual is expressed as cognitive style. While the children regulate their emotions, they undergo a cognitive process. In the problem solving process they experience to manage their emotions, they go through the stages of reflecting the emotion by reaching out to recognize emotions, processing and solution. Cognitive style and emotion regulation skills are related to the child's self-control. Considering that there may be a relationship between cognitive style and emotion regulation skills, this study was conducted to examine the relationship between 48-72 month-old children's cognitive styles and emotion regulation skills. The study is designed in a relational survey model. Data were collected through "Kansas Reflection-Impulsivity Scale for Preschoolers (KRISP) Form A" and "Emotion Regulation Scale (ERS)". The study group consists of 413 kindergarten students in Keçiören, Ankara in the 2018-2019 academic year. As a result of the research; when the relationship between the cognitive styles and emotion regulation skills of the children were examined, it was seen that there was a positive significant relationship between the KRISP-A Form error number score and the total score of the ERS negativity sub-factor. It was determined that there was no significant relationship between the fact that the children were fast correct, intellectual, intrinsic or slow wrong, and the sub-factors of emotion regulation scale and the total score of the scale.
\end{abstract}

Keywords: Preschool period, early childhood, cognitive style, emotion regulation, cognitive tempo.

\section{Giriş}

Okul öncesi dönem, gelişimin en hızlı olduğu ve çevresel etkilere en duyarlı olunan dönemdir. 0-6 yaş aralığını kapsayan okul öncesi dönemde çocuklar oldukça hızlı gelişim, değişim ve öğrenme potansiyeli göstermektedir (Aksoy ve Özkan, 2015; Kandır, 2001). Çocukların gelişimsel özellikleri birbirine benzer, ancak her birinin problem çözme sürecinde bilgiyi alma, kullanma ve hatırlama yolları birbirinden farklılaşabilmektedir. Algilama, düşünme, yargilama, hatırlama ve bilgi aktarma bireyden bireye değişkenlik gösterebilmektedir. Bireyden bireye değişen bu düşünsel faaliyetler, çocukların farklı bilişsel stillerinin olduğunu ve zekâ, yetenek, kişilik ve başarı bakımından farklı olduklarını gösterir. Bilişsel stiller, entelektüel yetenekleri, becerileri, kişiliği ve öğrenmeyi etkilemektedir (Danili ve Reid, 2006). Gander ve Gardiner (2010) bilişsel üslup olarak ifade ettikleri düşünme farklılıklarını "çocukların bireysel olarak zihinsel bir göreve yaklaşım tarzları" (s. 370) şeklinde tanımlarlar.

Düşünme biçimi veya bilişsel üslup olarak da ifade edilen bilişsel stil, çocuğun bireysel olarak bir problem durumuna yaklaşım şeklini ifade eder. Tarama/odaklaşma, alandan bağımsızlık/alana bağımlılık, kavramlaştırma üslupları ve bilişsel temponun da aralarında bulunduğu birçok bilişsel stil bulunmaktadır (Gander ve Gardiner, 2010). Çocuklar, sahip oldukları bilişsel stile göre problem çözerken hızlı ya da yavaş cevaplama eğiliminde olabilmektedir. Çocuklarda hızlı cevaplama eğilimi, onların problemi doğru bir biçimde çözümlemekten ziyade hata yapmalarına yol açabilmektedir. Yavaş hareket ederek dikkatli bir şekilde problem çözme eğilimi ise daha az hata yaparak çözüme ulaşmayı sağlamaktadır (Seçer vd., 
2009). Bir problem karşısında uzun süre düşünerek az deneme ile çözüme ulaşan çocuklar, düşünsel (reflektif) olarak; hızlı düşünerek çok sayıda hata yapan çocuklar içtepisel (impulsif) olarak; hızlı düşünerek ve az hata yaparak çözüme ulaşan çocuklar hızlı doğrucu olarak; uzun süre düşünerek geç tepkide bulunan ve çok sayıda hata yapan çocuklar ise yavaş yanlışçı çocuklar olarak adlandırılmaktadır (Seçer, Çeliköz ve Yaşa, 2008). Çocukların bir problem çözme durumunda hızlı ya da yavaş tepki verme tercihleri bilişsel tempo olarak ifade edilmektedir. Bilişsel tempo, içtepisel (problem karşısında hızlı tepki gösteren) ya da düşünsel (problem karşısında yavaş tepki gösteren) olabilir. İnsanların \%70 gibi önemli bir kısmının bilişsel stili düşünsel ve içtepisel bilişsel stil türündedir. Bu nedenle pek çok araştırmacı bilişsel stili sadece bu iki boyutu çerçevesinde ele almıştır (Gander ve Gardiner, 2010; Reuchlin, 1991, akt. Doğan, 2013). Yurtiçinde yapılan az sayıda çalışmada bilişsel stil dört farklı boyutu ile (içtepisel, düşünsel, hızlı doğrucu ve yavaş yanlışçı) ele alınmıştır. Bu araştırmalara göre çocukların bilişsel stillere göre dağılımı farklılık göstermektedir. Ceylan (2008) tarafından okul öncesi dönemdeki çocukların bilissel tempoları ile yaratıcılık düzeyleri arasındaki ilişkiyi incelemek amacıyla yapılan çalışmada çocukların bilişsel stillerinde en yüksek frekansın hızlı doğrucu bilişsel stile sahip çocuklara ait olduğu, bunu sırasıyla düşünsel, yavaş yanlış̧̧ı ve içtepisel çocukların takip ettiği görülmüştür. Kaya Bağdaş (2018) Ahıska Türkü ve Türk çocukların bilişsel stillerine göre ahlaki ve sosyal kural algıları arasındaki farkı incelediği çalışmasında hızlı doğrucu ve içtepisel çocukların frekanslarının aynı olduğunu, düşünsel ve yavaş yanlışçı çocukların frekanslarının ise daha düşük olduğunu tespit etmiştir. Durak Demirhan (2012) tarafından yapılan, okul öncesi eğitim kurumlarına devam eden 5-6 yaş çocuklarının bilişsel tempolarının ve davranış sorunları düzeylerinin belirlenmesini, içtepisel bilişsel stile sahip çocuklara uygulanacak eğitim programı ile bilişsel tempolarının düşünsellik yönünde geliştirilmesi yoluyla davranış problemlerinin azaltılmasına katkıda bulunmanın amaçlandığı çalışmada ise çocukların çoğunun içtepisel olduğu, bunu sırasıyla hızlı doğrucu, düşünsel ve yavaş yanlışçı çocukların takip ettiği görülmüştür.

İlgili alanyazın incelendiğinde bilişsel stilin cinsiyet, yaş, anne baba öğrenim düzeyi gibi çeşitli demografik değişkenler (Seçer vd., 2009), ebeveyn davranışları (Doğan, 2013), işitsel muhakeme ve işlem becerileri (Er, 2012), öğrenme güçlüğü (Seçer ve Sarı, 2014), ilkokula hazırbulunuşluk (Kayılı ve Koçyiğit, 2014), sosyal problem çözme becerileri (Aksoy ve Özkan, 2015), sosyal yetkinlik (Özkan ve Yaralı, 2016), iletişim becerileri ve duygusal beceriler (Kayılı ve Erbay, 2019), dikkati toplama becerisi (Seçer ve Özmen, 2015), kaygı, güdü ve beklentiler (Kagan, 1966), modelleme (Brown, 1985), kültürel farklılıklar (Smith ve Caplan, 1988), duygusal ve davranışsal ifadeler (Fisher, 2009) kapsamında incelendiği görülmüştür.

Araştırmaların sonucunda bilişsel stil farklılıklarının çocukların akademik, sosyal ve duygusal yaşantıları ile çeşitli demografik değişkenlerle ilişkili olduğu bulunmuştur. Yapılan araştırmalarda bilişsel stilde yaşa göre farklılaşma olduğu, küçük çocukların içtepiselliklerinin fazla olduğu, yaşın ilerlemesiyle birlikte düşünselliğin arttığ1 tespit edilmiştir (Salkind ve Nelson, 1980; Seçer vd., 2009). Kültürel farklılıklar bilişsel stilde farklılığa yol açmazken (Smith ve Caplan, 1988), anne baba öğrenim düzeyi ile kardeş sayısının farklılığa yol açtığı belirtilmiştir. Kardeş sayısı çok olan çocuklar ve anne baba öğrenim düzeyi düşük olan çocukların daha çok 
içtepisel, kardeş sayısı az olan çocuklar ve anne baba öğrenim düzeyi yüksek olan çocukların ise daha çok düşünsel bilişsel stile sahip oldukları görülmüştür (Aksoy ve Özkan, 2015; Özkan ve Yaralı, 2016; Seçer vd., 2009).

Yapılan araştırmalara göre, içtepisel bilişsel stile sahip çocukların saldırgan ve kendini denetleme yeteneğinin düşük olduğu (Gander ve Gardiner, 2010), akran ilişkilerinde saldırganlığa yatkın oldukları (Özkan ve Yaralı, 2016), duygusal becerilerde daha zayıf oldukları ve daha sık akran reddine maruz kaldıkları (Kayılı ve Erbay, 2019), doğru davranışı seçme konusunda daha az duyarlılık gösterdikleri, düşünsellere göre daha çok yanılgıya düşme, düzensizlik ve dikkat dağınıklığı yaşadıkları (Er, 2012), ahlaki ve sosyal kuralları daha az ciddiye aldıkları ve daha çok sosyal problemler yaşayabildikleri (Seçer, Çeliköz ve Yaşa, 2008) ortaya çıkmıştır. Ayrıca içtepisel bilişsel stil ile akademik yetersizlik arasında pozitif yönde bir ilişki olduğu (Vigil-Colet ve Morales-Vives, 2005) tespit edilmiştir.

Düşünsel bilişsel stile sahip çocukların ise daha kaygılı olabildikleri (Gander ve Gardiner, 2010), içtepisel bireylere göre sosyal mantık yürütme ve problem çözmede doğrudan duruma odaklanarak tepki gösterme eğiliminde oldukları (Peters ve Bernfeld, 1983), sosyal problem çözme becerilerinin içtepisellere göre daha yüksek olduğu ve sosyal problemlerini kişiler arası olumlu ilişkiler kurarak çözme eğiliminde oldukları (Aksoy ve Özkan, 2015), akranlarıyla daha olumlu ilişkiler kurdukları (Gomes ve Livesey, 2008) görülmektedir. Ayrıca, düşünsel çocukların, işitsel muhakeme ve işlem becerilerinin (Er, 2012), öz yeterliliklerinin ve benlik algılarının (Tozduman Yaralı ve Güngör Aytar, 2019), alıcı dil becerilerinin ve ilkokula hazır bulunuşluklarının (Kayılı ve Koçyiğit, 2014), duyguları anlama ve ifade etme ile toplam duygusal becerilerinin daha yüksek olduğu, sözel iletişimde daha yüksek puanlar elde ettikleri ve iletişim engellerini önledikleri (Kayılı ve Erbay, 2019) görülmektedir.

Bilişsel stil, kişinin kendisini denetlemesiyle ilgili bir kavramdır. Kendini denetleme ile ilgili bir başka kavram olan duygu düzenleme, kişinin kendisinin ve başkalarının duygularını anlama, duygularını ifade etme, olumsuz duygular ile baş etme ve olumlu duyguların devamlılığını sağlama becerilerini kapsamaktadır. Duygu düzenleme becerileri çocukların aile dışında sosyalleşmeye başladığı okul öncesi dönemde oldukça kritik bir öneme sahiptir (Arı ve Yaban, 2016; Bozkurt Yükçü ve Demircioğlu, 2017; Calkins ve Hill, 2007). Nitekim çocukların sosyal yetkinlik, akran kabulü, okul başarısı ve günlük hayata uyum sağlayabilmeleri için duygusal ve davranışsal olarak kendilerini yönetebilmeleri gerekmektedir.

Çocukların duygu deneyimleri, ifadeleri ve yönetimi kişilerarası bir bağlamda yaş ve deneyimle birlikte gelişir (Ertan, 2013; Fox ve Calkins, 2003; Fosco ve Grych, 2012). Duygu düzenleme becerilerinin gelişiminde sosyal bağlam ve etkileşime ek olarak, çocuğun dil gelişimi ve bilişsel gelişiminin de büyük bir etkisi olduğu bilinmektedir (Arı ve Yaban, 2016; Bozkurt Yükçü ve Demircioğlu, 2017; Gerow, 2014; Kurbet, 2010; Thompson, 1994). Duygusal durumlar karşısında çocuklar düşünme ve karar alma süreçleriyle davranışlarını oluşturarak çevreye uyum sağlayabilmektedir. Çocuklar duygularını düzenlerken, bilişsel bir süreç geçirirler. Duygularını yönetmek için yaşadıkları problem çözme sürecinde duyguları tanıma, işleme ve çözüme ulaşarak duyguyu yansıtma aşamalarından geçmektedir (Durmuşoğlu Saltalı, 2010; Kay1lı ve Erbay, 2019). 
Duygu düzenleme becerileri çocuğun içinde bulunduğu duygu durumunun çocuğu rahatsız ettiği ya da onun sosyal çevreye uyumunu güçleştiren problem durumlarda ihtiyaç duyulan becerilerdir. Bu becerilerin gelişiminde daha önce de ifade edildiği üzere aile, kültür ve içinde bulunulan kişilerarası bağlam gibi dişsal unsurlar kadar, bilişsel süreçlerin de etkisi olduğu bilinmektedir. Ayrıca bilişsel stil ve duygu düzenleme becerisinin bireyin kendini denetlemesiyle ilgili olduğu görülmektedir. Bunlardan hareketle, bilişsel stil ile duygu düzenleme becerileri arasında bir ilişki olabileceği düşünülmüş, ancak alanyazında böyle bir ilişkinin olup olmadığını inceleyen bir araştırmaya rastlanamamıştır. Bu nedenle mevcut araştırmanın bilişsel stil ile duygu düzenleme becerileri arasında ilişki olup olmadığının incelenmesi bakımından alanyazına katkı sağlayacağı düşünülmektedir. Ayrıca ile ilgili araştırmalarda bilişsel stilin yukarıda da ifade edildiği üzere ağırlıklı olarak içtepisellik ve düşünsellik boyutları kapsamında ele alındığı, dört boyutu birden ele alan az sayıda araştırma olduğu görülmüştür (Ceylan, 2008; Durak Demirhan, 2012; Kaya Bağdaş, 2018). Mevcut araştırmada ise bu iki boyuta ek olarak, hızlı doğrucu ve yavaş yanlışçı boyutları da inceleme kapsamına alınmıştır. Araştırmanın bilişsel stili dört farklı boyutu ile incelenmesi bakımından da ilgili alanyazına katkı sağlayacağı düşünülmektedir.

Araştırmada çocukların bilişsel stilleri ile duygu düzenleme becerileri arasında ilişkinin incelenmesi amaçlanmıştır. Bu amaç doğrultusunda aşağıdaki sorulara yanıt aranmıştır:

1. Çocukların bilişsel stilleri nasıldır?

2. Çocukların duygu düzenleme beceri düzeyleri nasıldır?

3. Çocukların bilişsel stilleri ile duygu düzenleme becerileri arasında anlamlı bir ilişki var midır?

\section{Yöntem}

Okul öncesi eğitim kurumlarına devam eden 48-72 aylık çocukların bilişsel stilleri ile duygu düzenleme becerileri arasındaki ilişkinin incelendiği araştırmada ilişkisel tarama modeli kullanılmıştır. İlişkisel tarama modeli iki ve daha çok sayıdaki değişken arasındaki birlikte değişim derecesini belirlemeyi amaçlayan çalışmalarda kullanılır (Karasar, 2012).

\section{Çalışma Grubu}

Araştırmanın çalışma grubunu 2018-2019 eğitim öğretim yılında Ankara ili merkez ilçelerinden Keçiören ilçesinde bulunan resmi okul öncesi eğitim kurumları arasından rastgele seçilen 2 bağımsız anaokulu ve 2 ilkokula bağlı anasınıfı olmak üzere toplam 4 okulda eğitim gören 413 çocuk oluşturmaktadır. Örneklem, uygun örnekleme yöntemi kullanılarak belirlenmiştir. Keçiören ilçesinde bulunan okulların seçilmesinin temel sebebi örnekleme ulaşılabilirliğin kolay olmasıdır. Çalışma grubunda yer alan toplam 413 çocuğun \%46,2'sini bağımsız anaokullarında, \%52,8'nin ilkokula bağlı anasınıflarında öğrenim gören çocuklar oluşturmaktadır. Araştırmaya katılan çocukların \%47'si kız ve \%53'ü erkektir. Çocukların \%28,8'i 48-60 aylık, \%71,2'si ise 6072 ayliktır. 


\section{Veri Toplama Araçları}

Araştırmada verilerin toplanması amacıyla, "Kansas Okul öncesi Dönemdeki Çocuklar İçin Düşünsellik-İçtepisellik Ölçeği A Formu" ve "Duygu Düzenleme Ölçeği" kullanılmıştır.

Kansas okul öncesi çocuklar için düşünsellik-içtepisellik ölçeği A formu (KRISP-A). Wright'ın (1971) geliştirmiş olduğu (The Kansas Reflection-Impulsivity Scale) KRISP-A ölçeği çocukların hızlı doğrucu, düşünsel, içtepisel ve yavaş yanlışçı olup olmadiklarını belirlemek amacıyla kullanılmaktadır ve toplam 10 şekilden oluşmaktadır. Uygulamaya başlarken beş örnek şekil ile alıştırma yapılmakta ardından asıl uygulamaya geçilmektedir. Ölçek her çocuğa bireysel olarak uygulanmakta ve uygulama yaklaşık olarak 25-30 dakika sürmektedir. Uygulama esnasında ölçekte bulunan şekiller çocuğa sırayla gösterilir. Hedef şekil ve bu şekle benzerlikleri fazla olan şekillerin yer aldığı görseller çocuğa aynı anda sunulur. Araştırmacı “Bak X, bu sayfada bir top var. Bu topun aynısı olan topu senin önündeki sayfada yer alan top çizimleri içinden bul ve göster" talimatını verdiği an kronometreye basarak çocuğun ilk verdiği cevap süresini çocuk adına düzenlenmiş olan kâğıda not alır. Çocuğun verdiği cevap yanlışsa doğru cevabı bulması için teşvik edilir. Doğru yanıta ulaşana dek yaptığı hataların sayısı cevap kâğıdına not alınır. Her çocuğun ölçekten elde ettiği toplam cevap verme süresi ve hata sayısı ayrı ayrı toplanır. Çocukların bilişsel stil türlerini belirlemek amacıyla uygulanan KRISP A Formuna göre yapılan sınıflandırma Tablo 1'de gösterilmektedir.

Tablo 1.

Tepki Süresi ve Hata Sayısına Göre Belirlenen Bilişsel Stil Sınılandırması

\begin{tabular}{|c|c|c|}
\hline \multirow{3}{*}{ 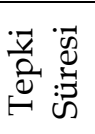 } & Düşünsel & Yavaş Yanlışçı \\
\hline & Hizlı Doğrucu & İçtepisel \\
\hline & \multicolumn{2}{|c|}{ Hata Sayısı } \\
\hline
\end{tabular}

1. Hızlı doğrucular: KRISP-A Formunda ortanca değerin altında yanlış sayısına ve yanitlama süresine sahip bireylerdir.

2. Düşünseller (Reflektifler/Yavaş Doğrucular): Ölçekte ortanca değerin altında yanlış sayısına ve ortanca değerin üzerinde yanıtlama süresine sahip olan, bir diğer ifadeyle, formu yavaş cevaplayan ve az sayıda hata yapan bireylerdir.

3. İçtepiseller (İmpulsifler/Hızlı Yanlışçılar): Ölçekte ortanca değerin üzerinde yanlış yaparak ortanca değerinin altında yanıtlama süresine sahip olan, bir diğer ifadeyle, formu hızlı cevaplayan ancak çok sayıda hata yapan bireylerdir.

4. Yavaş yanlışçılar: Ölçekte ortanca değerinin üzerinde hata sayısına ve yanitlama süresine sahip olan bireylerdir (Seçer, Çeliköz ve Yaşa, 2008).

KRISP-A formunun geçerlik ve güvenirlik çalışmaları Seçer, Çeliköz, Koçyiğit, Seçer ve Kayılı (2010) tarafından gerçekleştirilmiştir. Ölçeğin geçerlilik çalışmalarında kapsam geçerliği ve görünüş geçerliliği için uzman görüşü alınmıştır. Ölçeğin güvenirliğini araştırmak için puanlayıcı güvenirliği, test tekrar test ve testi yarılama güvenirliği incelenmiştir. Konya ilinde okul öncesi eğitim kurumlarına devam eden 6 yaş grubundaki toplam 30 çocuk iki ayrı gözlemci tarafından puanlayıcı güvenirliği için değerlendirilmiştir. Çocukların KRISP-A Formu'na yönelik tepki süreleri değerlendirilmiş ve gözlemciler arasındaki korelasyon $r=0.83$, hata sayısına yönelik 
değerlendirmede korelasyon $\mathrm{r}=0.78$ bulunmuştur. Test tekrar test güvenirliğini incelemek amacıyla Konya il merkezinde okul öncesi eğitim kurumlarındaki beş-altı yaş arasında 303 çocuk seçilmiştir. İki hafta ara ile iki kez uygulanan ölçeğin iki uygulama puanları arasındaki Pearson korelasyon katsayısı incelenmiştir. Korelasyon değerleri KRISP-A formu hata sayısı için $r=0.74$, tepki süresi için $r=0.89$ bulunmuştur. Yapılan iki ayrı uygulama sonrasında elde edilen sonuca göre uygulamalar arasında pozitif yönde anlamlı bir ilişki olduğu belirlenmiş ve tutarlılığının iyi düzeyde olduğu sonucuna ulaşılmıştır. Güvenirlik araştırması için uygulanan testi yarılama yönteminde KRISP-A formunda Spearman-Brown ile hesaplanan korelasyon değeri; tepki süresi için $r=0.85$, hata sayısı için ise $r=0.71$ olarak bulunmuştur (Koçyiğit ve Kayılı, 2014; Seçer, Çeliköz, Koçyiğit, Seçer ve Kayılı, 2010).

Duygu düzenleme ölçeği (DDÖ). Duygu Düzenleme Ölçeği (Emotion Regulation Checklist) çocukların duygu düzenleme becerisini ölçmek için Shields ve Cicchetti (1997) tarafından geliştirilmiştir. Türkçe uyarlaması Altan (2006) tarafından yapılmıştır. DDÖ, duygudaki yoğunluğu, değişkenliği, esnekliği ve aynı zamanda duygusal ifadenin ortama uygunluğunu değerlendiren $4^{\prime} l u ̈$ likert tipinde 24 maddeden oluşmaktadır: "hiçbir zaman/nadiren" 1 puan, "bazen" 2 puan, "sık sık" 3 puan "neredeyse her zaman." Ölçekte bazı maddeler (4, 5, 9, 11, 16 ve 18) ters puanlanmaktadır. Ölçekten alınan yüksek puan çocukların duygu düzenleme becerisinin yüksek olduğunu ifade etmektedir. Öğretmen ya da ebeveyn tarafından doldurulabilen DDÖ iki alt faktörden oluşmaktadır.

1.Değişkenlik/Olumsuzluk (D/O) faktörü (16 madde), çocuktaki duygu durum değişkenliği ile olumsuz duygulanım gösterme eğilimini ölçmektedir.

2.Duygu Düzenleme (DD) alt faktörü (8 madde) çocuğun duygularını ortama uygun olarak ifade etme becerisini ölçmektedir.

Altan (2006) çalışmasında ölçeğin geneline yönelik iç tutarlık katsayısı anne tarafından doldurulan formda .75, öğretmen tarafından doldurulan formda ise .84 olarak hesaplanmıştır. Alanyazında ölçekle ilgili yapılan çalışmalar incelendiğinde geçerli, güvenilir ve iç tutarlığı yüksek bir ölçme aracı olduğu görülmüştür (Altan, 2006; Batum ve Yağmurlu, 2007).

\section{Verilerin Toplanması ve Analizi}

Ankara İl Milli Eğitim Müdürlüğünden gerekli izinler alındıktan sonra belirlenen okullar ziyaret edilmiştir. Okul müdürleri ile görüşülerek veri toplama araçlarından "DDÖ" öğretmenler aracılığıyla ailelere ulaştırılarak aileler tarafından doldurulmuştur. "KRISP-A Formu" ise araştırmacı tarafindan her çocuğa okulun uygun, gruptan ayrı ve sessiz bir alanında bireysel olarak uygulanmıştır. Ölçek uygulanırken çocukların tepki sürelerinin ölçülmesi amacıyla kronometre kullanılmıştır. Uygulama esnasında her bir çocuğun tepki süresi ve hata sayısı kendisi için düzenlenmiş olan bir kâğıda not alınmıştır. Ölçeğin uygulama süresi her bir çocuk için ortalama 20 dakika sürmüştür.

Verilerin analizinde, çocukların bilişsel stillerinin nasıl olduğunu belirlemek için, KRISP-A Formuna verdikleri yanıtlar hata sayıları ve tepki süreleri hesaplanarak, ölçeğin düşünme süreleri ve hata sayısı faktörlerine ilişkin betimsel istatistikler belirlenmiştir. Belirlenen düşünme süreleri ve hata sayılarının ortalaması alınarak çocuklar hızlı doğrucular, düşünseller, içtepiseller ve yavaş yanlışçılar olarak gruplanmıştır. Çocukların duygu düzenleme becerilerinin nasıl dağıldığını belirlemek 
için DDÖ'nin faktör puanlarının ve ölçek toplam puanlarının betimsel istatistikleri hesaplanmıştır. Ölçeklerin faktör puanlarından ve toplam puanından elde edilen çarpıklık katsayı değeri ve standart hataları ile Kolmogorov-Smirnov test sonuçlarına göre verinin normal dağılım sergilemediği görülmüştür. Bu nedenle çocukların bilişsel stilleri ile duygu düzenleme becerileri arasında anlamlı bir ilişki olup olmadığını belirlemek için çocukların DDÖ alt faktör puanları ve ölçek toplam puanları ile KRISPA Formundan elde edilen tepki süresi ve hata sayıları için Sperman Korelasyon katsayısı hesaplanmıştır. Ayrıca çocukların bilişsel stilleri ile duygu düzenleme becerileri arasında anlamlı bir ilişki olup olmadığını belirlemek için çocukların DDÖ alt faktör puanları ve ölçek toplam puanının bilişsel stil gruplarına göre karşılaştırılmasında Kruskal Wallis H testi kullanılmıştır (Büyüköztürk, 2004).

\section{Bulgular}

Bu bölümde araştırma bulguları her alt probleme ilişkin olarak verilmiştir.

\section{Birinci Araştırma Sorusuna Yönelik Bulgular}

Çocukların bilişsel stilleri ve duygu düzenleme becerileri arasındaki ilişki incelenirken öncelikle çocukların KRISP-A formundan aldıkları tepki süresi ve hata sayıları hesaplanmıştır. Elde edilen bulgular Tablo 2' de verilmiştir.

Tablo 2

KRISP-A Formu Puanlarna İlişkin Betimsel İstatistikler

\begin{tabular}{lccccccccc}
\hline Faktörler & $n$ & Min & Max & Ort. & Ss & Ortanca & Mod & Çarpıklkk & Basıklkk \\
\hline Tepki Süresi (sn.) & 413 & 24 & 215 & 57.36 & 21.35 & 54 & 55 & 2.280 & 10.266 \\
\hline Hata Sayıs1 & 413 & 0 & 22 & 6.57 & 3.89 & 6 & 5 & 0.934 & 1.020 \\
\hline
\end{tabular}

KRISP-A Formunun tepki süresi ortalamasının $(X=57.36)$, hata sayılarının ortalamasının $(X=6.57)$ olduğu görülmektedir. Tepki süresine ilişkin alınan minimum değer 24 ve maksimum değer $215^{\prime}$ dir. Hata sayılarına ilişkin alınan minimum değer 0 ve maksimum değer $22^{\prime}$ dir. Tepki süresine ilişkin ortalamanın mod değerinden büyük olduğu görülmektedir. Buna göre dağılımın sağa çarpık olduğu söylenebilir. Ayrıca tepki süresine ilişkin çarpıklık katsayısı pozitif (10.266) ve basıklık katsayısı, normalden şişkin bir dağılım göstermiştir. Sağa çarpık bir dağılım olması sebebiyle çocukların tepki süreleri ortalamanın altında bir yığılma göstermiştir. Çocukların aldıkları puanlara bakıldığında, tepki süresine göre ortalama değerin altında olan çocukların sayısı 252 ve ortalama değerin üstünde olan çocukların sayısı 161'dir. Hata sayısına ilişkin ortalamanın mod değerinden büyük olduğu görülmektedir. Buna göre dağılımın sağa çarpık olduğu söylenebilir. Ayrıca hata sayısına ilişkin çarpıklık katsayısı pozitif $(0,934)$ ve basıklık katsayısı, normalden şişkin bir dağılım göstermiştir. Sağa çarpık bir dağılım olması sebebiyle çocukların hata sayıları ortalamanın altında bir yığılma göstermiştir. Çocukların aldıkları puanlara bakıldığında, hata sayılarına göre ortalama değerin altında olan çocukların sayısı 235 ve ortalama değerin üstünde olan çocukların sayısı 178'dir. Çocukların KRISP-A Formundan elde ettikleri süresi ve hata sayısı puanlarının ortalama değerlerine göre çocuklar dört gruba ayrılmıştır. Bu hesaplamalar çerçevesinde çalışmaya katılan çocukların bilişsel stil türlerine dağılımları Tablo 3 'te sunulmuştur: 
Tablo 3

Bilişsel Stil Türleri

\begin{tabular}{lcccc}
\hline & $f$ & $\%$ & Tepki Süresi (sn.) & Hata Sayısı \\
\hline Hızlı doğrucular & 157 & 38.0 & $<57.36$ & $<6.57$ \\
\hline Düşünseller & 81 & 19.6 & $>57.36$ & $<6.57$ \\
\hline İçtepiseller & 95 & 23.0 & $<57.36$ & $>6.57$ \\
\hline Yavaş yanlış̧̧lar & 80 & 19.4 & $>57.36$ & $>6.57$ \\
\hline
\end{tabular}

Düşünme süreleri ve hata sayılarına göre çocukların çoğunlukla hızlı doğrucu (\%38.0) bilişsel stile sahip oldukları görülmüştür. Bunu sırasıyla içtepisel (\%23.0) , düşünsel (\%19.6) ve yavaş yanlışçı (\%19.4) çocuklar takip etmektedir.

\section{İkinci Araştırma Sorusuna Yönelik Bulgular}

Araştırmaya katılan çocukların duygu düzenleme becerilerini ölçmek için kullanılan DDÖ'ne ilişkin alt faktör puanları ve ölçek toplam puanlarının betimsel istatistikleri hesaplanmıştır. Elde edilen bulgular Tablo 4'te gösterilmiştir.

Tablo 4

Duygu Düzenleme Ölçeği Puanlarına İlişkin Betimsel İstatistikler

\begin{tabular}{lccccccc}
\hline Faktörler & $n$ & Min & Max & Ort. & Std.S & Çarpıklık & Basıklık \\
\hline Değişkenlik/Olumsuzluk & 413 & 19.00 & 54.00 & 30.51 & 5.931 & 0.701 & 0.765 \\
\hline Duygu Düzenleme & 413 & 15.00 & 32.00 & 25.28 & 3.323 & -0.294 & -0.051 \\
\hline Ölçek Toplam & 413 & 43.00 & 80.00 & 55.79 & 5.705 & 0.576 & 0.604 \\
\hline
\end{tabular}

DDÖ'nin değişkenlik/olumsuzluk faktör puan ortalamasının (= 30.51), duygu düzenleme faktör puan ortalamasının (= 25.28) ve ölçek toplam puan ortalamasının ise (= 55.79) olduğu görülmektedir. Değişkenlik/olumsuzluk faktörüne ilişkin alınan minimum değerin 19 ve maksimum değerin 54 olduğu göz önüne alındığında ortalama puanın yüksek olmadığı söylenebilir. Çocukların aldıkları puanlara bakıldığında, değişkenlik/olumsuzluk faktörü ortalamasının altında olan çocukların sayısı 228 ve ortalamanın üstünde olan çocukların sayısı 185' dir. Buna karşılık, duygu düzenleme faktöründen alınan minimum değerin 15 ve maksimum değerin 32 olduğu göz önüne alındığında bu faktöre ilişkin ortalama puanın yüksek olduğu belirtilebilir. Duygu düzenleme faktörü ortalamasının altında olan çocukların sayısı 212 ve ortalamanın üstünde olan çocukların sayısı 201'dir. DDÖ'nin toplam puanına ilişkin alınan minimum değerin 43 ve maksimum değerin 80 olduğu göz önüne alındığında, ölçek toplam puan ortalamasının yüksek olmadığı söylenebilir. Ölçek toplam puan ortalamasının altında kalan çocukların sayısı 214 ve ortalamanın üstünde olan çocukların sayısı 199'dur.

\section{Üçüncü Araştırma Sorusuna Yönelik Bulgular}

Çalışma grubundaki çocukların bilişsel stilleri ile duygu düzenleme becerileri arasında anlamlı bir ilişki olup olmadığını incelemek için Sperman Korelasyon Katsayısından yararlanılmıştır. DDÖ alt faktör puanları ve ölçek toplam puanları ile düşünme süreleri ve hata sayıları arasında anlamlı fark olup olmadı̆̆ı incelenmiştir. Elde edilen sonuçlar Tablo 5'te gösterilmektedir. 
Tablo 5

DDÖ ve KRISP-A Formu Puanlarn Arasındaki Spearman Korelasyon Testi Sonuçlarn

\begin{tabular}{lccc}
\hline & $\begin{array}{c}\text { Değisskenlik/ } \\
\text { Olumsuzluk }\end{array}$ & $\begin{array}{c}\text { Duygu } \\
\text { Düzenleme }\end{array}$ & $\begin{array}{c}\text { Duygu Düzenleme } \\
\text { Ölçek Toplam }\end{array}$ \\
\hline Tepki süresi & 0,02 & $-0,02$ & 0,01 \\
\hline Hata Sayısi & $0,13^{*}$ & -0.06 & $0,11^{*}$ \\
\hline${ }^{*} \mathrm{p} \leq 0.05$ & & &
\end{tabular}

Araştırmaya katılan çocukların DDÖ'nin alt faktör puanları ve ölçek toplam puanları ile KRISP-A Formundan elde ettikleri tepki süreleri arasında anlamlı bir ilişki bulunamamıştır. Ancak çocukların DDÖ'nin alt faktör puanları ve ölçek toplam puanları ile KRISP-A Formundan elde ettikleri hata sayıları arasında anlamlı bir ilişki olduğu görülmüştür. Çocukların değişkenlik/olumsuzluk faktör puanları ile hata sayıları arasında $r=0,13$ ve DDÖ toplam puanları ile hata sayıları arasında $r=0,11$ düzeyinde anlamlı bir ilişki bulunmuştur. Yani çocukların hata sayıları arttıkça duygu durum değişkenliği ile olumsuz duygulanım gösterme eğilimi artmaktadır. Korelasyon katsayısı 0.30'dan küçük olması halinde değişkenler arasındaki ilişkinin düşük düzeyde bir ilişki olduğu bilinmektedir (Büyüköztürk, 2004).

Çocukların bilişsel stil türleri ile duygu düzenleme becerileri arasında anlamlı bir ilişki olup olmadığını incelemek için DDÖ alt faktör puanları ve ölçek toplam puanları Kruskal Wallis H Testi bilişsel stil gruplarına göre karşılaştırılmıştır. Elde edilen bulgular Tablo 6'da yer almaktadir.

Tablo 6

Bilişsel Stil Türlerine Göre Duygu Düzenleme Ölçeği Puanlarna İlişkin Kruskal Wallis H-Testi Sonuçları

\begin{tabular}{|c|c|c|c|c|c|c|c|}
\hline & Bilişsel Stil Türleri & $n$ & $X$ & Ss. & Stra Ort. & $X^{2}$ & $p$ \\
\hline \multirow{4}{*}{ Değişkenlik/Olumsuzluk } & Hızlı Doğrucular & 157 & 29.77 & 5.42 & 194.46 & \multirow{4}{*}{4.61} & \multirow{4}{*}{0.20} \\
\hline & Düşünseller & 81 & 30.04 & 5.57 & 199.98 & & \\
\hline & İçtepiseller & 95 & 31.36 & 6.38 & 221.97 & & \\
\hline & Yavaş Yanlışçılar & 80 & 31.41 & 6.50 & 220.95 & & \\
\hline \multirow{4}{*}{ Duygu Düzenleme } & Hizlı Doğrucular & 157 & 25.54 & 3.39 & 216.32 & \multirow{4}{*}{3.20} & \multirow{4}{*}{0.36} \\
\hline & Düşünseller & 81 & 25.45 & 2.95 & 215.17 & & \\
\hline & İçtepiseller & 95 & 25.04 & 3.55 & 196.26 & & \\
\hline & Yavaş Yanlışçılar & 80 & 24.87 & 3.24 & 193.18 & & \\
\hline \multirow{4}{*}{ Ölçek Toplam } & Hizlı Doğrucular & 157 & 55.32 & 5.19 & 198.97 & \multirow{4}{*}{1.86} & \multirow{4}{*}{0.60} \\
\hline & Düşünseller & 81 & 55.50 & 5.25 & 203.36 & & \\
\hline & İçtepiseller & 95 & 56.41 & 6.15 & 218.52 & & \\
\hline & Yavaş Yanlışçılar & 80 & 56.28 & 6.49 & 212.76 & & \\
\hline
\end{tabular}

Tablo 6 incelendiğinde, bilişsel stil gruplarına göre çocukların değişkenlik/olumsuzluk faktör puanları $\left(X^{2}=4.61 ; p>0.05\right)$, duygu düzenleme faktör puanları $\left(X^{2}=3.20 ; p>0.05\right)$ ve ölçek toplam puanlarının $\left(X^{2}=1.86 ; p>0.05\right)$ bilişsel stil türlerine göre anlamlı farklılık göstermediği görülmüştür Çocukların bilişsel stil türlerine göre duygu düzenleme becerilerinin değişmemesi dikkat çekmektedir. Bilişsel stil türlerinin belirlenmesinde rol oynayan ölçek hata sayısı puanları duygu düzenleme becerisiyle anlamlı ilişki gösterirken, çocukların hangi bilişsel stilde olduklarının duygu düzenlemelerine etki etmedikleri görülmektedir. 


\section{Tartışma, Sonuç ve Öneriler}

Çalışma grubundaki çocukların KRISP-A Formundan elde edilen verilere göre düşünme sürelerinin $(X=57.36 \mathrm{sn}$.) ve hata sayılarının $(X=6.57)$ ortalamanın altında bir yığılma gösterdiği sonucuna ulaşılmıştır (Tablo 2). Aydoğmuş Bayar (2018)'ın 237 çocuk ile yaptığı çalışmada, tepki süresi ortalaması 96.76 (sn.); hata sayısı ortalaması da 9,32 olarak bulunmuştur. Tozduman Yaralı ve Güngör Aytar (2019) tarafından 60 çocuk ile yapılan çalışmada ise, tepki süresi ortalaması 41.82 (sn.); hata sayısı ortalaması da 4,83 olarak bulunmuştur.

Düşünme süreleri ve hata sayılarına göre çocukların çoğunlukla hızlı doğrucu bilişsel stile sahip oldukları görülmüştür (Tablo 3). Bunu sırasıyla içtepisel, düşünsel ve yavaş yanlışçı çocuklar takip etmektedir. Alanyazın incelendiğinde çocukların bilişsel stillerine göre frekans değerleri benzerlik göstermektedir. Ceylan (2008) çalışmasında çocukların bilişsel stillerinde en yüksek frekansın hızlı doğrucu bilişsel stile sahip çocuklara ait olduğu görülmektedir. Bunu sırasıyla düşünsel, yavaş yanlışçı ve içtepisel çocuklar takip etmektedir. Kaya Bağdaş (2018) çalışmasında hızlı doğrucu ve içtepisel çocukların frekanslarının aynı olduğu, düşünsel ve yavaş yanlış̧̧ı çocukların frekanslarının ise daha düşük olduğu görülmektedir. Durak Demirhan'ın (2012) çalışmasının bulguları ise farklılık göstermekte, çocukların çoğunun içtepisel olduğu, bunu sırasıyla hızlı doğrucu, düşünsel ve yavaş yanlışçı çocukların takip ettiği belirtilmektedir. Çalışmalarda genel olarak hızlı doğrucu çocukların sayısının fazla olması benzerlik göstermektedir.

Çalışma grubundaki çocukların DDÖ'nin alt faktörleri olan değişkenlik/olumsuzluk faktörü, duygu düzenleme faktörü ve ölçek toplam puanlarının ortalamanın altında yı̆̆ılma gösterdiği sonucuna ulaşılmıştır. Çocukların duygu durum değişkenliği ile olumsuz duygulanım gösterme eğiliminin ve duygularını düzenleyebilme becerilerinin düşük olduğu söylenebilir. Alanyazındaki çalışmalardan Akbaba (2017) çalışmasındaki çocukların duygu düzenleme becerilerinin yüksek, değişkenlik olumsuzluk özelliklerinin ise orta düzeyde olduğu saptanmıştır. Bozkurt Yükçü (2017) çalışmasında, çocukların duygu düzenleme becerilerinin yüksek olduğu ifade edilmiştir. Alanyazınla DDÖ betimsel istatistiklerinden elde edilen bulguların farklılık gösterdiği görülmektedir. $\mathrm{Bu}$ farklılığın çalışma gruplarına özgü demografik farklılıklardan kaynaklanmış olabileceği düşünülebilir.

Çocukların bilişsel stilleri ile duygu düzenleme becerileri arasında anlamlı bir ilişki incelendiğinde, çocukların KRISP-A Formu tepki süresi ile DDÖ alt faktörler ve ölçek toplam puanı arasında anlamlı ilişki görülmemiştir. Çocukların KRISP-A Formu hata sayıları ile duygu düzenleme faktörü arasında anlamlı ilişki görülmezken, değişkenlik/olumsuzluk faktörü ve ölçek toplam puanı arasında pozitif yönde anlamlı ilişki olduğu sonucuna ulaşılmıştır. Buna göre, olumsuz duygulanım gösterme eğilimi olan çocukların hata sayılarının arttı̆̆ı söylenebilir.

Çocukların, karşılaştıkları bir olaya duygusal tepki vermeden önce duygu düzenleme becerisi ile olayla ilgili bilişsel stratejiler geliştirildikleri ve daha sonra duygusal bir tepki verdikleri belirtilmektedir (Aktürk 2016; Schore, 2011). Kayılı ve Erbay (2019) çalışmalarında düşünsel çocukların içtepisel çocuklardan daha yüksek düzeyde iletişim ve duygusal becerilere sahip olduğunu ileri sürmektedir. Yani, düşünsel çocukların içtepisel çocuklara göre duyguları anlama ve ifade etmede daha 
yetenekli oldukları görülmektedir. İçtepisel çocuklar bir problemle karşılaştıklarında hata sayıları fazla olan çocuklardır. Bu araştırmada, çocukların olumsuz duygulanım gösterme eğilimleri arttıkça hata sayılarının artması bulgusu (Tablo 5) alanyazınla paralellik göstermektedir. Olumsuz davranışları yüksek olan çocukların yaşadıkları farklı duygusal süreçlerin onların hata yapma eğilimini arttırabileceği, çocukların gelişim özelliklerinin, aile yapısının, yaşadığı sosyal süreçler gibi durumların bunda etkili olabileceği düşünülmektedir.

Çalışmaya katılan çocukların bilişsel stil türleri ile duygu düzenleme becerileri arasında anlamlı ilişki olup olmadığı incelenmiştir. Çocukların hızlı doğrucu, düşünsel, içtepisel veya yavaş yanlışçı olmaları ile DDÖ alt faktörleri ve ölçek toplam puanı arasında anlamlı ilişki olmadığı sonucuna ulaşılmıştır. Anlamlı ilişki olmamasının, çocukların duygu düzenleme becerilerini ölçmek için kullanılan DDÖ ölçeği verilerinin anneler aracılığı ile toplanmasından, birlikte evde yaşanan süreçlerde aile tutumlarından, çocukların yerine ailelerin problemleri çözmelerinden ve araştırmanın gözlem, görüşme gibi nitel veriler ile desteklenmemesinden kaynaklanmış olabileceği düşünülmektedir.

Araştırmaya katılan çocukların bilişsel stilleri incelendiğinde sayıca en fazla olan hızlı doğrucu çocukları içtepisel çocukların takip ettiği görülmüştür. İçtepisel çocuklar için model olmanın önemli olduğu bilinmektedir (Brown, 1985). Buradan hareketle, bir problemle karşılaşıldığında, problemin çözümüne karar vermede acele etmemek noktasında öğretmen ve ebeveynlerin model olması önerilebilir. Örneğin, çocukların karşılaşacakları problem durumlarının simülasyonu yapılarak acele ettiklerinde ya da düşünerek hareket edildiğinde nasıl sonuç oluşturduğu gösterilebilir.

Çocukların, bilişsel stil türleri ile duygu düzenleme becerileri arasında anlamlı ilişki olmadığ1 görülmüştür. Ölçekler aracılığı ile elde edilen verilere ek olarak, çocukların bilişsel stil türlerinin ve duygu düzenlemelerinin günlük yaşama nasıl yansıdı̆̆ını belirlemek amacıyla gözlem temelli çalışmalar yapılabilir. Ayrıca farklı bilişsel stildeki çocukların, ilerleyen yıllardaki duygularını yönetme becerileri, davranış problemi gösterme eğilimleri ve sosyal ilişkilerine yönelik boylamsal araştırmalar yapılabilir.

$\mathrm{Bu}$ araştırmanın örneklemi Ankara ili Keçiören ilçesinde bulunan Milli Eğitim Bakanlığına bağlı yarım gün eğitim veren ilkokullara bağlı anasınıfı ve anaokullarındaki 48-72 aylık çocuklarla sınırlıdır. Araştırma; köy okulları, tam gün eğitim veren özel ve devlet okulları dâhil edilip örneklem çeşitlendirilerek yenilenebilir. Özel ve devlet okulları arasında karşılaştırma yapılabilir.

\section{Kaynakça}

Akbaba, G. (2017). Beş ve altı yaş çocuklarının duygu düzenlemesinde çocuk mizacıyla anne davranışları arasındaki etkileşimin incelenmesi (Yayımlanmamış Yüksek lisans Tezi). İstanbul Üniversitesi, İstanbul.

Aksoy, A.B. ve Özkan, H.K. (2015). Çocukların bilişsel tempoları ile sosyal problem çözme becerilerinin bazı demografik özellikler açısından incelenmesi (Kırklareli il merkezi örneklemi). Bartın Üniversitesi Eğitim Fakültesi Dergisi, 4(2), 401-417.

Aktürk, B. (2016). Oyun tabanlı psikoeğitim programının boşanmış aileye sahip okul öncesi çocukların duygu düzenleme beceri düzeylerine etkisi (Yayımlanmamış Yüksek lisans Tezi). Melikşah Üniversitesi, Kayseri. 
Altan, Ö. (2006). The effects of maternal socialization and temperament on children's emotion regulation (Unpublished Master's Thesis). Koç University, İstanbul.

Arı, M., ve Yaban, E.H. (2016). Okul öncesi dönemdeki çocukların sosyal davranışları: Mizaç ve duygu düzenlemenin rolü. Hacettepe Üniversitesi Eğitim Fakültesi Dergisi, 31(1), 125-141. DOI:10.16986/HUJE.2015014655

Aydoğmuş Bayar, S. (2018). 48-72 aylık çocukların bilişsel stilleri ile baba katılımı arasındaki ilişkinin incelenmesi (Yayımlanmamış Yüksek lisans Tezi). Maltepe Üniversitesi, İstanbul.

Batum, P. and Yağmurlu, B. (2007). What counts in externalizing behaviors? The contributions of emotion and behavior regulation. Current Psychology: Developmental Learning Personality Social, 25(4), 272-294. https:// doi.org/10.1007/BF02915236

Brown, S. D. (1985). The interaction of conceptual tempo and modeling on motor performance (learning style) (Unpublished doctoral dissertation). Louisiana State University, USA.

Bozkurt Yükçü, Ş. (2017). Bağımsız anaokullarına devam eden çocukların duygu düzenleme ve sosyal problem çözme becerileri ile ebeveynlerinin duygusal okuryazarlık düzeyleri arasındaki ilişkinin incelenmesi (Yayımlanmamış Yüksek lisans Tezi). Hacettepe Üniversitesi, Ankara.

Bozkurt Yükçü, Ş. ve Demircioğlu, H. (2017). Okul öncesi dönem çocuklarının duygu düzenleme becerilerinin çeşitli değişkenler açısından incelenmesi. Mehmet Akif Ersoy Üniversitesi Eğitim Fakültesi Dergisi, 44, 442-466. https:// doi.org/10.21764/maeuefd.336085

Büyüköztürk, Ş. (2004). Sosyal bilimler için veri analizi el kitabı: Istatistik, araştırma deseni SPSS uygulamaları ve yorum. Ankara: Pegem Akademi.

Büyüköztürk, Ş., Çokluk, Ö., ve Köklü, N. (2018). Sosyal bilimler için istatistik. Ankara: Pegem Akademi.

Ceylan, E. (2008). Okul öncesi eğitime devam eden 5-6 yaş çocuklarının bilişsel tempoya göre yaratıcılık düzeyinin incelenmesi (Yayımlanmamış Yüksek lisans Tezi). Selçuk Üniversitesi, Konya.

Danili, E. and Reid, N. (2006). Cognitive factors that can potentially affect pupils' test performance. Chemistry Education Research and Practice, 7, 64-83. https:/ / doi.org/10.1039/B5RP90016F

Durak Demirhan, T. (2012). Bilişsel tempo eğitimi programının 5-6 yaş çocuklarının bilişsel tempoları ve davranış sorunlarına etkisinin incelenmesi (Yayımlanmamış Doktora Tezi). Marmara Üniversitesi, İstanbul.

Durmuşoğlu Saltalı, N. (2010). Duygu eğitiminin okul öncesi dönem çocuklarının duygusal becerilerine etkisi (Yayımlanmamış Doktora Tezi). Selçuk Üniversitesi, Konya.

Gander, J. M. ve Gardiner, H. W. (2010). Çocuk ve ergen gelişimi (ss. 370-373). Ankara: İmge.

Gomes, L. and Livesey, D. (2008). Exploring the link between impulsivity and peer relations in 5-and 6-year-old children. Child: Care, Health and Development, 34(6), 763-770. https:/ / doi.org/10.1111/j.1365-2214.2008.00878.x

Kandır, A. (2001). Çocuk gelişiminde okul öncesi eğitim kurumlarının yeri ve önemi. Milli Ĕ̆itim Dergisi, 151, 102-104. 
Karasar, N. (2012). Bilimsel araştırma yöntemleri. Ankara: Nobel.

Kaya Bağdaş, Ç. (2018). Anasınıfı ve ilkokul 1. Sınıfa devam eden Ahıska Türkü ve Türk Çocuklarını bilişsel stillerine göre ahlaki ve sosyal kural algilarının incelenmesi (Yayımlanmamış Yüksek lisans Tezi). Ankara Yıldırım Beyazıt Üniversitesi, Ankara.

Kayılı, G. and Erbay, F. (2019). A comparison of preschool children's communication and emotional skills on the basis of their cognitive tempos. Early Child Development and Care, 189(4), 625-634. https:/ / doi.org/10.1080/03004430.2017.1336168

Koçyiğit, S. ve Kayılı G. (2014). Farklı bilişsel tempoya sahip anaokulu çocuklarının ilkokula hazır bulunuşluklarının incelenmesi. Eğitim ve Bilim Dergisi, 39(175) 1426. http:/ / dx.doi.org/10.15390/EB.2014.3449

Kurbet, H. (2010). Anaokuluna devam eden çocukların duygusal düzenleme becerileri ile annelerinin empatik eğilim ve tutumlarının incelenmesi (Yayımlanmamış Yüksek lisans Tezi). Gazi Üniversitesi, Ankara.

Özkan H. K. ve Yaralı Tozduman K. (2016). Beş-altı yaş çocuklarının bilişsel stilleri ile sosyal yetkinlik ve davranış durumlarının incelenmesi. Kastamonu Ĕ̆itim Dergisi, 24(5), 2195-2206.

Schore, A. (2011). Gelişimsel nörobiyoloji ve bă̆lanma kuramı. (Arık. M, Çev.) İzmit: Psikoterapi Enstitüsü Eğitim.

Seçer, Z., Çeliköz, N. ve Yaşa, S. (2008). Okul öncesi dönemdeki çocukların bilişsel stillerine göre ahlaki ve sosyal kural anlayışları. Selçuk Üniversitesi Sosyal Bilimler Enstitüsü Dergisi, 20, 561-576.

Seçer, Z., Çeliköz, N., Koçyiğit, S., Seçer, F., and Kayılı, G. (2010). Social skills and problem behaviours of children with different cognitive styles who attend preschool education. Australian Journal of Guidance and Counselling, 20(1), 91-98. https:// doi.org/10.1375/ajgc.20.1.91

Seçer, Z. ve Özmen, S. K. (2015). Dikkat toplamayı geliştirici etkinliklerin içtepisel okul öncesi çocukların düşünme ve dikkat toplama becerilerine etkisi. Kastamonu Eğitim Dergisi, 23(4), 1803-1816.

Seçer, Z. ve Sarı, H. (2014). Düşünme eğitimi programının impulsif özellikli öğrenme güçlüğüne sahip çocukların bilişsel stillerine etkisi. Ĕ̆itim ve Bilim Dergisi, 39(171), 26-36.

Seçer, Z., Sarı, H., Çeliköz, N. ve Üre, Ö. (2009). Okul öncesi dönemdeki çocukların bilişsel stillerinin bazı değişkenler açısından incelenmesi. Selçuk Üniversitesi Sosyal Bilimler Enstitüsü Dergisi, 21, 407-420.

Shields, A. and Cicchetti, D. (1997). Emotion regulation among school-age children: the development and validation of a new criterion q-sort scale. Developmental Psychology, 33(6), 906-916. https:/ / doi.org/10.1037/0012-1649.33.6.906

Smith, J. D. and Caplan, J. (1988). Cultural differences in cognitive style development. Developmental Psychology, 24(1), 46-52. https:/ / doi.org/10.1037/0012-1649.24.1.46

Tozduman Yaralı, K., ve Güngör Aytar, F. (2019). Okul öncesi çocukların bilişsel tempolarına göre benlik algılarının incelenmesi. Sosyal Bilimler ve Eğitim Dergisi, 2(2), 287-299.

Wright, J. C. (1971). Kansas Reflection-Impulsivity Scale for Preschoolers (KRISP). St. Louis: CEMREL, Inc. 


\section{Summary}

\section{Introduction}

Children show a very rapid development, change and learning potential during the preschool years (Aksoy \& Özkan, 2015; Kandır, 2001). The developmental characteristics of children are similar, but in the problem solving processes the ways each get, use, and remember information may differ. These differences show that children have different cognitive styles. Cognitive styles effect intellectual abilities, skills, personality and learning (Danili and Reid, 2006).

Children, depending on the cognitive style that they have, may approach solving problems quickly or slowly (Seçer et al., 2009). The preferences of children to react quickly or slowly in a problem solving process are called cognitive tempo. Cognitive tempo can be impulsive (responding quickly to the problem) or reflective (responding slowly to the problem). A great deal of people, such as $70 \%$ are either impulsive or reflective in their cognitive style. For this reason, many researchers have studied cognitive style only in terms of these two dimensions ( Gander \& Gardiner , 2010; Reuchlin, 1991 , as cited in Doğan, 2013). In a small number of studies conducted in Turkey, cognitive style has been investigated in four different (quick corrective, reflective, impulsive or slow false) dimensions. According to these studies, the distribution of children in different cognitive styles differs (Ceylan, 2008; Durak Demirhan, 2012; Kaya Bağdaş, 2018).

When the related literature is reviewed, it was found that cognitive style is investigated in relation to various demographic variables such as gender, age, and parental education level (Seçer et al., 2009), parental behaviors (Doğan, 2013), auditory reasoning and processing skills (Er, 2012), learning difficulties (Seçer and Sarı , 2014), elementary school readiness (Kayılı \& Koçyiğit, 2014), social problem solving skills (Aksoy \& Özkan, 2015), social competence (Özkan \& Yaralı, 2016), communication skills and emotional skills (Kayllı \& Erbay, 2019), attention management skills (Seçer \& Özmen, 2015), anxiety, motivation and expectations (Kagan , 1966), modeling (Brown, 1985), cultural differences (Smith \& Caplan , 1988), emotional and behavioral expressions (Fisher, 2009). According to research cognitive style differences are associated with children's academic (Er, 2012; Kayılı \& Koçyiğit, 2014; Peters \& Bernfeld, 1983; Vigil-Colet \& Morales-Vives, 2005) , social and emotional (Aksoy \& Özkan, 2015; Gander \& Gardiner, 2010; Gomes \& Livesey, 2008; Kayılı \& Erbay, 2019; Özkan \& Yaralı, 2016; Seçer, Çeliköz \& Yaşa, 2008; Tozduman Yaralı \& Güngör Aytar, 2019), experiences and various demographic variables (Aksoy \& Özkan, 2015; Özkan \& Yaralı, 2016; Salkind \& Nelson, 1980; Seçer et al., 2009).

Emotion regulation skills are of critical importance during the preschool period when children start socializing outside of their families (Ar1 \& Yaban, 2016; Bozkurt Yükçü \& Demircioğlu, 2017; Calkins \& Hill, 2007). Indeed, children need to be able to manage their emotions and their behaviors in order for social competence, peer acceptance, school performance and to be able to adapt to the daily life in general.

Children's emotional experiences, expressions, and management develop with age and experience in an interpersonal context (Ertan, 2013; Fox \& Calkins , 2003; Fosco $\&$ Grych , 2012). In addition to social context and interaction, it is known that language development and cognitive development of the child have a great impact on the development of emotion regulation skills (Ar1 \& Yaban, 2016; Bozkurt Yükçü \& 
Demircioğlu, 2017; Gerow, 2014; Kurbet, 2010; Thompson, 1994). In the face of emotional situations, children can adapt to the environment by forming their behavior through thinking and decision making processes. While children regulate their emotions, they undergo a cognitive process. In the problem solving process that they experience to manage their emotions, they go through the stages of recognizing emotions, processing and solving them, and reflecting emotion (Durmuşoğlu Saltalı, 2010; Kayılı \& Erbay, 2019).

Emotion regulation skills are needed in problem situations where the emotional state of the child disturbs the child or makes it difficult to adapt to the social environment. As mentioned earlier, cognitive processes are known to have an impact on the development of these skills, as well as external factors such as family, culture and interpersonal context. Given that, it was thought that there might be a relationship between emotion regulation skills and cognitive styles. However, a review of the literature revealed no research investigating the relationship between emotion regulation skills and cognitive styles. In this study, it was aimed to examine whether there is a significant relationship between children's cognitive styles and their emotion regulation skills. For this purpose, answers to the following questions were sought:

1. How are the cognitive styles of children?

2. How are the emotion regulation skills of children?

3. Is there a significant relationship between children's cognitive styles and their emotion regulation skills?

\section{Method}

The research was designed in relational survey model. The sample of the study consisted of 413 children aged 48-72 months who attended pre-school education institutions in Keçiören district of Ankara province in the 2018-2019 academic year. The data were collected through the scale of "Thinking-Internality Scale A Form for Children in Kansas Preschool Period (KRISP-A Form)" and "Emotion Regulation Scale (DDÖ)" were used. The "KRISP-A Form" was applied to each child individually in a suitable, separate and quiet area of the school by the researcher. While applying the form, a stopwatch was used to measure the reaction times of the children. During the application, the response time and the number of errors of each child were noted on a paper prepared for him. The DDÖ was delivered to the families through teachers, and was collected by teachers again after a ten-day period. The data were analyzed using Kruskal Wallis H test, Sperman Correlation test in addition to descriptive statistics.

\section{Results}

As a result of the research it was found that based on the response time and number of the mistakes they made, most of the children had quick corrective cognitive style followed in order by impulsive, reflective and slow false cognitive styles.

No significant relationship was found between children response time and their scores on DDÖ in scale total and in sub-scales. However there was a positive relationship between children's number of mistakes and their scores the variability / negativeness sub-scale and in scale total.

Finally no significant relationship was found between children's cognitive styles (quick corrective, reflective, impulsive or slow false) and in their scores on DDÖ in scale total and in sub-scales. 


\section{Discussion}

When the literature is examined, it is stated that children experience negative processes in their cognitive development as a result of not meeting their emotional and physical needs (Aktürk 2016; Schore, 2011). It is also suggested that before emotional reaction related to an event that individuals encounter with emotion regulation, cognitive strategies are developed first and then an emotional response is given (Aktürk 2016; Schore, 2011). Kayllı and Erbay (2019) argue that intellectual children have higher levels of communication and emotional skills than internal children. In other words, it is seen that intellectual children are more talented in understanding and expressing emotions compared to internal children. The findings of the study are in line with the literature in terms of the increase in the number of errors that children make when they encounter a problem as their tendency to show negative effect increases.

\section{Araştırmanın Etik Taahhüt Metni}

Yapılan bu çalışmada bilimsel, etik ve alıntı kurallarına uyulduğu; toplanan veriler üzerinde herhangi bir tahrifatın yapılmadığı, karşılaşılacak tüm etik ihlallerde "Cumhuriyet Uluslararası Eğitim Dergisi ve Editörünün" hiçbir sorumluluğunun olmadığ1, tüm sorumluluğun Sorumlu Yazara ait olduğu ve bu çalışmanın herhangi başka bir akademik yayın ortamına değerlendirme için gönderilmemiş olduğu sorumlu yazar tarafından taahhüt edilmiştir.

\section{Authors' Biodata/ Yazar Bilgileri}

Hatice Büşra YILMAZ Gazi Üniversitesi Eğitim Bilimleri Enstitüsü'nde Araştırma Görevlisi olarak görev yapmaktadır.

Hatice Büşra Yılmaz works at Gazi University, Intitute of Education as a Research Asisstant.

Aysel TÜFEKCİ Gazi Üniversitesi Eğitim Fakültesi Temel Eğitim Bölümü'nde Dr. Öğr. Üyesi olarak görev yapmaktadır.

Aysel Tüfekci works at Gazi University, Faculty of Education, Department of Primary Education as an Assistant Professor. 